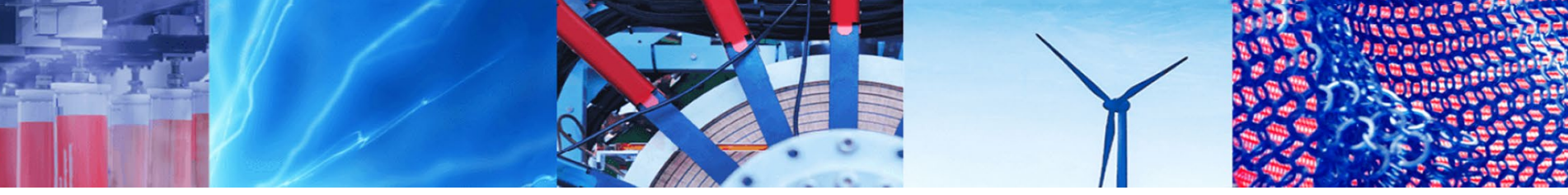

Short Communication

\title{
Effects of human serum on the stability and cytotoxicity of silver nanoparticles
}

\author{
D. C. Kennedy ${ }^{1}$ (D) V. Gies ${ }^{1} \cdot$ A. Jezierski ${ }^{2} \cdot$ L. Yang $^{1}$
}

Received: 30 July 2019 / Accepted: 10 October 2019 / Published online: 30 October 2019

(c) Crown 2019

\begin{abstract}
Silver nanoparticles are ubiquitous in today's commercial marketplace. Despite decades of research, there is still disagreement about the risk that silver nanoparticles pose to human and environmental health. There is often a lack of correlation between measured physical properties and the measured biological endpoints, making it difficult to establish trends, and discrepancies between different cell models have not been clearly accounted for. Here we have used human $A B$ serum in cell culture media for the investigation in place of fetal bovine serum (FBS) which is typically used. In HepG2 cells, particle uptake was clearly correlated with smaller sizes of particles and with increased cytotoxicity. In neuron-like SH-SY5Y cells, similar trends were not observed. Compared with previously published data on the same particles in these cell lines with cell culture media supplemented with FBS, there are clear and significant differences in the stability of the particles, their cellular uptake and their cytotoxicity in these two commonly used cell models for in vitro cytotoxicity testing. This highlights the need for improved in vitro testing for nanomaterials and the importance of using human serum to better predict human in vivo outcomes.
\end{abstract}

Keywords Silver $\cdot$ Human serum $\cdot$ Toxicity $\cdot$ Uptake $\cdot$ Stability $\cdot$ Correlations $\cdot$ Risk assessment

\section{Introduction}

Silver nanoparticles are used for a variety of applications; however, the development of regulations for their safe use in food packaging, medicine and consumer goods is challenging due to the discrepancies between cytotoxic values in published literature [1-5]. This occurs largely because nanoparticles are highly sensitive to their environment and their surfaces interact with biomolecules, rapidly transforming them in cell culture media [6]. Silver nanoparticles are routinely used as anti-microbial agents [7-11]; however, the toxicity data for silver particles in mammalian cell lines [12-16] and in animal studies [17-21], remains inconclusive with respect to potential hazards that the particles might pose. Silver nanoparticles are particularly challenging to get accurate reproducible data for because they can rapidly dissolve in aqueous media under some conditions, or agglomerate and ultimately precipitate under other aqueous conditions [22-28]. This acute sensitivity to media conditions, is compounded by the fact that they behave very differently in different cell lines [29]. In this study, we sought to examine how making a single change to the culture medium, substituting fetal bovine serum (FBS) with human male $A B$ serum (HS), would affect the stability, uptake and cytotoxicity of the silver nanoparticles and whether trends in activity based on particle size would hold up under these conditions. Crucially, to make an accurate comparison of the effects of $\mathrm{HS}$, we have kept all other controllable parameters for the cell culture and assays the same in order to not introduce new

$\triangle$ D. C. Kennedy, david.kennedy@nrc-cnrc.gc.ca| ${ }^{1}$ Measurement Science and Standards, National Research Council Canada, 1200 Montreal Road, Ottawa K1A 0R6, Canada. ${ }^{2}$ Human Health and Therapeutics, National Research Council Canada, 1200 Montreal Road, Ottawa K1A 0R6, Canada. 
variables that could also affect the results. We have previously reported results using FBS and noted that even small changes such as the use of antibiotics in the media, are enough to alter the toxicity of the silver particles [29]. Nanoparticles are known to rapidly interact with serum proteins [6] and biomolecules such as antibiotics to form a corona around the particle. This corona likely plays a critical role in facilitating the uptake of the particles into cells.

In order to understand the particle behaviour in the human serum supplemented culture media, we performed a wide range of experiments previously performed on the same particles in media supplemented with FBS. For physical characterization in media, both dynamic light scattering (DLS) and UV-Vis spectroscopy measurements were made in cell culture media over a $72 \mathrm{~h}$ time period. We examined silver particles stabilized with either citrate or PVP of four different sizes spanning 10-60 nm. We then measured the cytotoxicity and metal uptake of the particles into both human hepatocytes (HepG2 cells) and neuron-like SH-SY5Y cells using an MTT assay as previously reported. We also measured the cytotoxicity using and lactate dehydrogenase (LDH) leakage assay that measures membrane integrity to confirm the findings of the MTT assay. Metal uptake of the particles into both cell lines was all masured. All of the results showed significant differences to those previously obtained from media with FBS and previous results have been included in tables where applicable in order to highlight these differences.

\section{Experimental}

\subsection{Materials}

Silver particles were purchased from Nanocomposix as aqueous suspensions. Particle coatings include polyvinylpyrrolidone (PVP) and citrate and ranged in size from 10 to $60 \mathrm{~nm}$ (10 nm PVP lot\# HKE0123, $20 \mathrm{~nm}$ PVP lot\# BAM0056, $40 \mathrm{~nm}$ PVP lot\#HKE0100, $60 \mathrm{~nm}$ PVP lot\# DAG3347, $10 \mathrm{~nm}$ citrate lot\# ECP1267, $20 \mathrm{~nm}$ citrate lot\# RRR0009, $40 \mathrm{~nm}$ citrate lot\#PSK0021, $60 \mathrm{~nm}$ citrate lot\# DAG3489). Sizes were validated by UV-Vis and DLS and data were compared to those supplied by Nanocomposix for the specific batch numbers.

\subsection{Cell culture}

SH-SY5Y and HepG2 cells (American Tissue Culture Center) were all grown in Dulbecco's modified Eagle's medium (DMEM) (Gibco) supplemented with 10\% Human male AB serum (HS) (Sigma) and 1\% penicillin-streptomycin (Pen/ strep) $(50 \mu \mathrm{g} / \mathrm{mL}$, Gibco) unless stated otherwise and under standard culture conditions $\left(37^{\circ} \mathrm{C}, 5 \% \mathrm{CO}_{2}\right)$. Media was filtered through $0.2 \mu \mathrm{m}$ filters after the addition of HS to remove any precipitates from the media. Cells were grown in T75 flasks (Falcon) and Trypsin-EDTA solution (Gibco) was used for passaging cells ( $3 \mathrm{~mL}$ per T75 flask for HepG2 and $2 \mathrm{~mL}$ for $\mathrm{SH}-\mathrm{SY} 5 \mathrm{Y}$ ). For passaging, SH-SY5Y cells were treated with Trypsin-EDTA at room temperature for $5 \mathrm{~min}$, while HepG2 cells were incubated for $10 \mathrm{~min}$ at $37^{\circ}$.

\subsection{UV-Vis spectroscopy}

Samples were run on a Varian Cary 5000 UV-Vis spectrometer at ambient temperature under a nitrogen atmosphere using plastic (Brand) cuvettes with a $1 \mathrm{~mL}$ sampling volume. $500( \pm 1) \mu \mathrm{L}$ of DMEM (no phenol red, Gibco) with $10 \% \mathrm{HS}$ and $1 \%$ Pen/strep was mixed with $500( \pm 1) \mu \mathrm{L}$ of silver particles suspended in water at $20( \pm 0.5) \mu \mathrm{g} / \mathrm{mL}$. This resulted in a final concentration of $5 \% \mathrm{HS}, 0.5 \%$ Pen/strep and $10 \mu \mathrm{g} / \mathrm{mL}$ silver nanoparticle. This media mixture was consistent with what was used for the cytotoxicity assays and has previously been used by our group to measure the same nanoparticles in media with FBS. At each time point a background of water/media without particles was measured to normalize any drift that might arise from the media changing over time. The first measurement was performed immediately after mixing the particles with media.

\subsection{Dynamic light scattering}

Samples were run on a Malvern Zetasizer Nano-ZS. Samples were run in plastic cuvettes (BRAND) with a $1 \mathrm{~mL}$ sample volume. Each sample was measured 5 times. All initial values for particles were consistent with manufactures specifications for the particles. Samples for time courses were prepared as 1:1 mixtures of DMEM (no phenol red) with $10 \% \mathrm{HS}$ and $1 \mathrm{Pen} /$ strep and silver particles suspended in water at $20 \mu \mathrm{g} / \mathrm{mL}$. This resulted in a final concentration of $5 \% \mathrm{FBS}$ and $10 \mu \mathrm{g} / \mathrm{mL}$ silver nanoparticle, the same as was used for the UV-Vis experiments. The first measurement was performed immediately after mixing the particles with media.

\subsection{MTT assay}

Cells were seeded into wells in a 96-well plate (Falcon) $\left(1 \times 10^{5}\right.$ cells $/ \mathrm{mL}, 100( \pm 0.5) \mu \mathrm{L}$ per well $)$ to cover a $9 \times 6$ grid, filling 54 wells. Remaining wells were filled with $200 \mu \mathrm{L}$ of PBS. After $24 \mathrm{~h}, 100( \pm 0.5) \mu \mathrm{L}$ volumes of dilutions of particles in water spanning from 20 to $0.1 \mu \mathrm{g} / \mathrm{mL}$ were added to the seeded wells (final concentrations spanning 10-0.05 $\mu \mathrm{g} /$ $\mathrm{mL}$ ). For each nanoparticle, eight dilutions were prepared and for each dilution six replicates were performed. In the remaining 6 wells, $100( \pm 0.5) \mu \mathrm{L}$ of water was added as a particle-free control. Cells were then incubated with 
nanoparticles for $72 \mathrm{~h}$. After $72 \mathrm{~h}, 50( \pm 0.5) \mu \mathrm{L}$ of a PBS solution of MTT $(2.5( \pm 0.1) \mathrm{mg} / \mathrm{mL})$ was added to each well and then incubated for $3 \mathrm{~h}$. After $3 \mathrm{~h}$, media was aspirated from all wells, leaving purple formazan crystals in those wells with viable cells. To each well, $150( \pm 1) \mu \mathrm{L}$ of DMSO was added. Plates were then agitated for $30 \mathrm{~s}$ to dissolve the crystals and analyzed using a plate reader (Fluorstar Omega, BMG Labtech.) to determine the absorbance of each well at $570 \mathrm{~nm}$. This reading divided by the average from the reading of the six control wells was plotted to determine the $\mathrm{IC}_{50}$ value of each complex for each cell line. Six replicates were performed for each sample on each cell line for each experiment, and each experiment was repeated three times. The values and errors reported were calculated from 18 unique measurements after curves were fit with a 4-variable sigmoidal curve to calculate the $\mathrm{IC}_{50}$ values. Statistical analysis was used to provide the error analysis for the calculated $I_{50}$ values derived from the fit curves.

\subsection{LDH assay}

LDH assay kits were purchased from Abcam. HepG2 and SH-SY5Y cells and nanoparticle dilutions were prepared in the same manner as for the MTT assay; however, only 3 replicates were performed for each particle and each experiment was repeated twice. After $72 \mathrm{~h}$ a high LDH control was produced by adding $20( \pm 0.5) \mu \mathrm{L}$ of cell lysis buffer to each of three wells that contained only cells and media. Low LDH control was measured from three wells that contained untreated cells and not lysed. Next, $10( \pm 0.2) \mu \mathrm{L}$ of media were removed from each well and transferred to a new 96-well plate. To each well was added $100( \pm 1) \mu \mathrm{L}$ of $\mathrm{LDH}$ solution from the kit. Plates were incubated at room temperature in the dark for $30 \mathrm{~min}$ and then centrifuged to remove any bubbles from the wells. The absorption from each well was then measured at $450 \mathrm{~nm}$. Toxicity curves were plotted and normalized using the high LDH control as a measure for $0 \%$ viability and the low LDH control for $100 \%$ viability. Statistical analysis was used to provide the error analysis for the calculated $I C_{50}$ values derived from the fit curves.

\subsection{Metal analysis}

To determine the AgNP uptake into each cell line, $5 \mathrm{~mL}$ cell suspensions of $10^{5}$ cells $/ \mathrm{mL}$ cells were plated into $3 \mathrm{~cm}$ Petri dishes. After $24 \mathrm{~h}, 250( \pm 1) \mu \mathrm{L}$ of nanoparticles (stock suspensions of $20 \mu \mathrm{g} / \mathrm{mL}$ ) were added to the cells. These samples were incubated for $24 \mathrm{~h}$, at which times the media was removed. The cells were rinsed by adding $5 \mathrm{~mL}$ of PBS to each dish and gently swirling the dish for $5 \mathrm{~s}$ to pass the PBS over the cells without causing them to detach from the dishes. The PBS was then pipetted away and this washing procedure repeated a second time. This rinse was performed to remove any particle containing media from the samples before isolating the cells. Trypsin-EDTA ( $2 \mathrm{~mL}$ of $0.25 \%$ ) was then added to detach the cells from the plate surface, and an additional $3 \mathrm{~mL}$ of PBS added to resuspend the cells. These suspensions were transferred to $15 \mathrm{~mL}$ conical Falcon tubes and centrifuged for $5 \mathrm{~min}$ at $800 \mathrm{rpm}$. The supernatant was discarded, and the cells were resuspended in $3 \mathrm{~mL}$ of PBS by pipetting them up and down for $20 \mathrm{~s}$ until cells appeared evenly dispersed. The suspensions was then centrifuged for $5 \mathrm{~min}$ at $800 \mathrm{rpm}$ again. This washing procedure was then repeated a second time in order to remove particles that might be adhered to the cell surface [30]. Cell pellets were then resuspended in $2 \mathrm{~mL}$ of PBS again and counted using a LUNA automated cell counter (Logos Biosystems). Cell suspensions ranged between 1 to $2 \times 10^{6}$ cells per sample for HepG 2 cells and between 0.5 and $1.5 \times 10^{6}$ cells per sample for SH-SY5Y cells. After counting the cells in each sample, the cells were centrifuged again for $5 \mathrm{~min}$ at $2000 \mathrm{rpm}$ and the supernatant discarded. The cell pellet was dried overnight. To each dried pellet, $100 \mu \mathrm{L}$ of concentrated nitric acid was added and the sample left for $24 \mathrm{~h}$ to be digested. Samples were then diluted with $\mathrm{H}_{2} \mathrm{O}$ and submitted for ICP-MS (Element XR, Thermo Fisher Scientific, Bremen, Germany) analysis to determine the silver content. The results were then normalized to the number of cells in each sample. Each experiment was repeated 3 times and the values and errors reported are the average of these 3 measurements. A control experiment in which the nanoparticles were incubated in media without cells, and then treated using the above protocol gave values that were below the detection limit for silver. This suggests that the rinsing and washing procedure is effective for removing the particles from the sample, though particles may still be stuck to the cell surface rather than internalized in cells.

\section{Results and discussion}

\subsection{Particle dynamics in cell culture media}

The stability of aqueous silver nanoparticles is dependent on several parameters including $\mathrm{pH}$, salinity, temperature and the dissolved oxygen concentration [27]. We have also shown that nanoparticles exhibit unique behaviour in cell culture media that has been supplemented with FBS, and that larger particles tend to be more stable in such cell culture media [29]. In this continuation of that work we have studied the stability of commercially sourced citrate and PVP-stabilized particles at 10,20, 40 and $60 \mathrm{~nm}$ in media supplemented with HS. Changing the type of serum used to better mimic a human environment has a significant 
impact on the stability of the particles and changes trends in stability that are observed in media with FBS. The particles were measured as a 1:1 mixture of the nanoparticle stock solution $(20 \mu \mathrm{g} / \mathrm{mL})$ and DMEM containing $1 \%$ pen/ strep and $10 \% \mathrm{HS}$ with spectral measurements made at $0,1,3,24,48$, and $72 \mathrm{~h}$ after mixing (Fig. 1). These are the exact same conditions used previously with FBS with only the type of serum being different. From Table 1 we can see that compared to previously published data in FBS, the particles of all sizes exhibit a smaller shift in the absorption maximum over $72 \mathrm{~h}$. This indicates that the changes arising over time from agglomeration, dissolution, and particle reshaping appear to be less pronounced in human serum supplemented media. The shifts for the PVP stabilized particles are considerably larger than for the citrate stabilized particles. This is consistent with what was observed previously in FBS. For the citrate stabilized particles, both the 10 and $20 \mathrm{~nm}$ particles show a significant decrease in the absorption peak intensity within the first hour in media with $\mathrm{HS}$, followed by a slower but constant decrease up until $72 \mathrm{~h}$. For both the 40 and $60 \mathrm{~nm}$ particles, the immediate drop is smaller in intensity, however, for both of these particles, a very significant decrease is observed between 3 and $24 \mathrm{~h}$. This suggests that these particles agglomerate over this time and settle out of suspension. This was observed as the formation of a red film on the
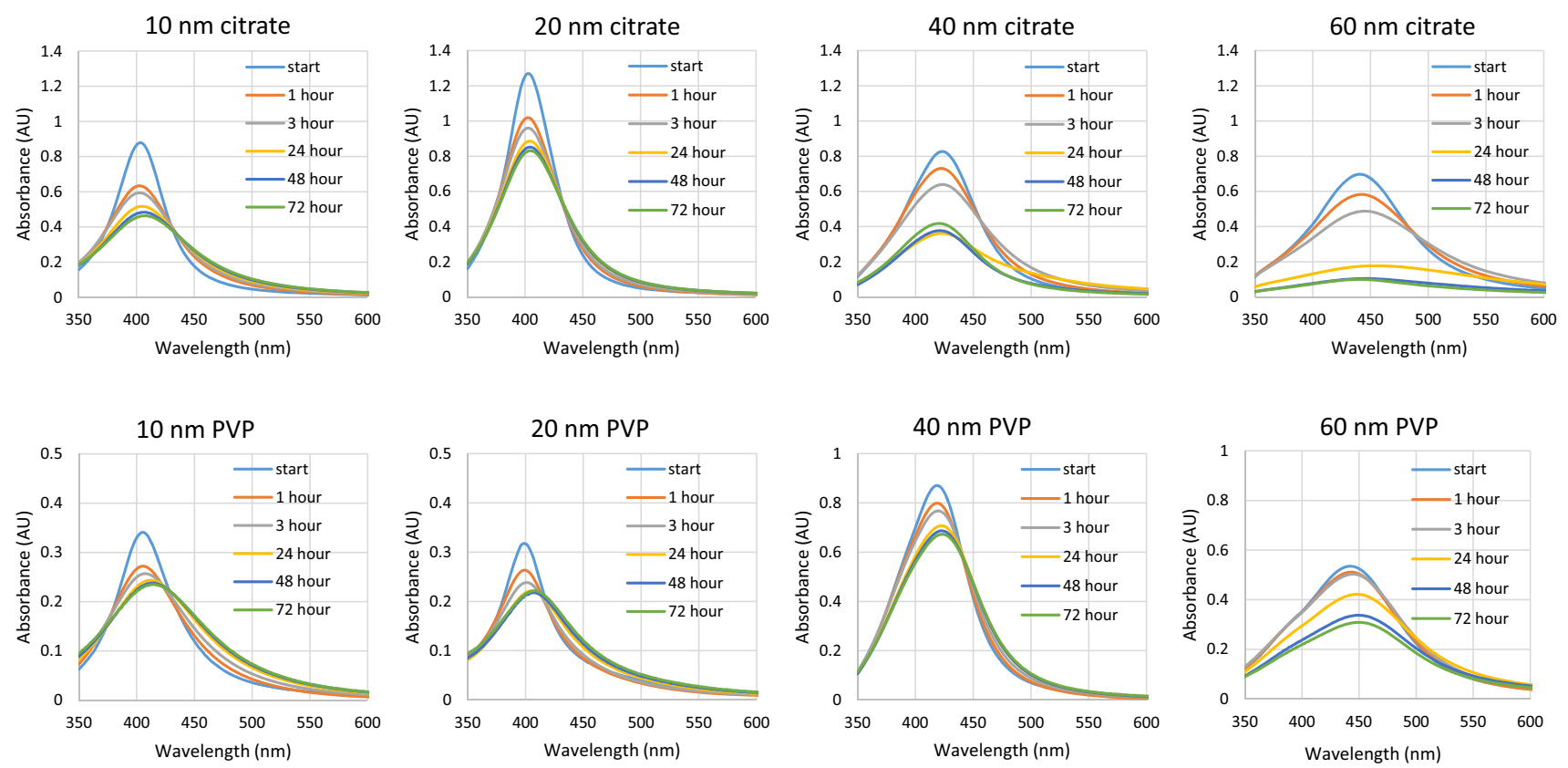

Fig. 1 UV-Vis spectra of silver nanoparticles ranging in size from 10 to $60 \mathrm{~nm}$ in diameter were recorded in cell culture media with a final concentration of $5 \%$ human male $A B$ serum. Spectra were recorded immediately upon mixing and then at $1,3,24,48$ and $72 \mathrm{~h}$

Table 1 Summary of the observed plasmonic absorption maxima for commercially tested silver nanoparticles ranging in size from 10 to $60 \mathrm{~nm}$ in media supplemented with human serum compared to media supplemented with fetal bovine serum

\begin{tabular}{|c|c|c|c|c|c|c|}
\hline \multirow[t]{2}{*}{ Sample } & \multicolumn{3}{|l|}{ In HS } & \multicolumn{3}{|l|}{ In FBS } \\
\hline & Initial $\lambda_{\max }(\mathrm{nm})$ & $72 \mathrm{~h} \lambda_{\max }(\mathrm{nm})$ & $\Delta \lambda_{\max }(\mathrm{nm})$ & Initial $\lambda_{\max }(\mathrm{nm})$ & $72 \mathrm{~h} \lambda_{\max }(\mathrm{nm})$ & $\Delta \lambda_{\max }(\mathrm{nm})$ \\
\hline $10 \mathrm{~nm}$ citrate & 404 & 409 & 5 & 405 & 414 & 9 \\
\hline $20 \mathrm{~nm}$ citrate & 403 & 405 & 2 & 403 & 411 & 8 \\
\hline $40 \mathrm{~nm}$ citrate & 424 & 425 & 1 & 423 & 428 & 5 \\
\hline $60 \mathrm{~nm}$ citrate & 442 & 443 & 1 & 441 & 445 & 4 \\
\hline $10 \mathrm{~nm}$ PVP & 406 & 415 & 9 & 403 & 413 & 10 \\
\hline $20 \mathrm{~nm}$ PVP & 399 & 410 & 11 & 402 & 411 & 13 \\
\hline $40 \mathrm{~nm}$ PVP & 419 & 425 & 6 & 416 & 429 & 13 \\
\hline $60 \mathrm{~nm}$ PVP & 443 & 451 & 8 & 432 & 459 & 27 \\
\hline
\end{tabular}

FBS data (in last three columns) previously reported [29] 
bottom of the cuvette. These results differ considerably from those previously reported for FBS. In FBS it was the $10 \mathrm{~nm}$ particles that precipitated more readily between 3 and $24 \mathrm{~h}$, while the 40 and $60 \mathrm{~nm}$ particles appeared relatively unchanged over this time period. The different behaviour of both the small and large particles in media supplemented with HS suggests that different processes are occurring at the particle surface with respect to protein corona formation that results in a different life cycles of the particles in this media. At the two size extremes tested here, the $10 \mathrm{~nm}$ particles were more stable and $60 \mathrm{~nm}$ particles less stable in media supplemented with HS compared to media with FBS reversing the trend in stability previously observed [29] as smaller particles were now more stable compared to larger ones in cell culture media with HS. The differences in stability may have a profound impact on their uptake into cells and their persistence in the body for in vivo applications.

The behaviour of the PVP-stabilized particles exhibits similar trends to the citrate stabilized particles. Both the 10 and $20 \mathrm{~nm}$ particles exhibit immediate decreases in intensity within the first hour, whereas the $60 \mathrm{~nm}$ particles decrease slowly over the first $3 \mathrm{~h}$, but then drop significantly between 3 and $24 \mathrm{~h}$. Interestingly, the $40 \mathrm{~nm}$ particles appear relatively stable and exhibit only a small decrease in intensity through the time course. For all of the PVP-stabilized particles there is a shift in the absorbance maximum to longer wavelength that is different than for the citrate stabilized particles and may indicate a change in the aspect ratio of the particles. Such a change has was previously observed for particles in media with FBS by TEM and was correlated to the shift in the absorption maximum for the PVP-stabilized particles [29]. Similar to the citrate stabilized particles, the overall trend for the PVP-stabilized particles in HS is that the smaller particles appear to be more stable over time.

DLS measurements were performed over a $72 \mathrm{~h}$ time course as well (Table 2). For the $10 \mathrm{~nm}$ citrate stabilized particles the hydrodynamic diameter remains constant throughout confirming the stability of these particles observed by UV-Vis. There is a small decrease between 24 and $48 \mathrm{~h}$ for the $20 \mathrm{~nm}$ particles and for the 40 and $60 \mathrm{~nm}$ particles, there is a significant increase over the first $24 \mathrm{~h}$, followed by a continual decrease - the values at 48 and $72 \mathrm{~h}$ being significantly smaller than the initial readings. These results suggest that both agglomeration and particle dissolution may be occurring but at different timescales for each particle size. For all of the PVP-stabilized particles, the hydrodynamic diameter increases over the first $24 \mathrm{~h}$, but then decrease from 24 to $72 \mathrm{~h}$, the final hydrodynamic diameters are similar to the original measurement for the 10,40 and $60 \mathrm{~nm}$ particles, and slightly smaller for the $20 \mathrm{~nm}$ particles. For the PVP-stabilized particles there is not an obvious correlation between the different trends observed by UV-Vis with the DLS measurements as all 4 sizes of particles seem to exhibit similar behaviour over time by DLS but differ considerably by UV-Vis. The DLS measurements also differ from previous results in media with FBS [29]. In FBS, the $10 \mathrm{~nm}$ citrate particles increased in size over the first $24 \mathrm{~h}$ before stabilizing, while the 20 , 40 and $60 \mathrm{~nm}$ particles did not change over $72 \mathrm{~h}$. For the PVP particles in FBS, the 10 and $20 \mathrm{~nm}$ particles decreased in size over the first $24 \mathrm{~h}$ before stabilizing, whereas the 40 and $60 \mathrm{~nm}$ PVP coated particles increased in size continuously over the $72 \mathrm{~h}$ time course.

\subsection{Toxicity of AgNPs}

MTT data assays were performed in both HepG2 and SHSY5Y cells for the 8 commercially sourced nanoparticles (Table 3). We have previously attempted to correlate trends in particle stability in media with FBS and toxicity data in the same media and found generally that smaller particles were more toxic based on their mass concentration. This was previously correlated with their poorer stability as well, however, as discussed in the previous
Table 2 Z-average hydrodynamic diameter as measured by DLS for commercially tested silver nanoparticles ranging in size from 10 to $60 \mathrm{~nm}$ in cell in media supplemented with human serum data is listed as average hydrodynamic diameter (standard error)/PDI value (standard error)

\begin{tabular}{lllll}
\hline Sample & Initial diameter $(\mathrm{nm}) / \mathrm{PDI}$ & $24 \mathrm{~h}$ diameter $(\mathrm{nm}) / \mathrm{PDI}$ & 48 h diameter $(\mathrm{nm}) / \mathrm{PDI}$ & $72 \mathrm{~h} \mathrm{diameter}(\mathrm{nm}) / \mathrm{PDI}$ \\
\hline $10 \mathrm{~nm}$ citrate & $50(2) / 0.56(0.03)$ & $47.9(0.8) / 0.57(0.01)$ & $50.2(0.4) / 0.55(0.05)$ & $48.9(0.6) / 0.54(0.03)$ \\
$20 \mathrm{~nm}$ citrate & $63(1) / 0.46(0.01)$ & $61(2) / 0.47(0.01)$ & $52(01) / 0.45(0.03)$ & $50(2) / 0.44(0.02)$ \\
$40 \mathrm{~nm}$ citrate & $114.5(0.8) / 0.26(0.01)$ & $141(3) / 0.6(0.1)$ & $76.5(0.7) / 0.42(0.02)$ & $68.1(0.4) / 0.36(0.03)$ \\
$60 \mathrm{~nm}$ citrate & $133(2) / 0.18(0.01)$ & $203(9) / 0.6(0.1)$ & $96.2(0.9) / 0.45(0.02)$ & $85(3) / 0.40(0.05)$ \\
$10 \mathrm{~nm}$ PVP & $56(3) / 0.56(0.02)$ & $60(1) / 0.55(0.03)$ & $52(1) / 0.56(0.04)$ & $53.0(0.05) / 0.54(0.01)$ \\
$20 \mathrm{~nm}$ PVP & $73.8(0.9) / 0.45(0.01)$ & $77(4) / 0.53(0.01)$ & $66(3) / 0.40(0.01)$ & $62(2) / 0.48(0.02)$ \\
$40 \mathrm{~nm}$ PVP & $64.9(0.6) / 0.27(0.01)$ & $98(7) / 0.49(0.03)$ & $62.0(0.3) / 0.6(0.2)$ & $67(2) / 0.28(0.01)$ \\
$60 \mathrm{~nm}$ PVP & $89.9(0.9) / 0.19(0.01)$ & $143(5) / 0.44(0.01)$ & $100(1) / 0.25(0.01)$ & $91(2) / 0.26(0.01)$ \\
\hline
\end{tabular}


Table 3 Reported values are $I_{50}$ values using an MTT or LDH assay for $10-60 \mathrm{~nm}$ silver nanoparticles in each cell line after $72 \mathrm{~h}$ and are reported in $\mu \mathrm{g}$ silver $/ \mathrm{mL}$ in media supplemented with human serum compared to media supplemented with fetal bovine serum

\begin{tabular}{|c|c|c|c|c|c|c|}
\hline \multirow[t]{2}{*}{ Sample } & \multicolumn{2}{|c|}{ MTT in HS } & \multicolumn{2}{|c|}{$\mathrm{LDH}$ in HS } & \multicolumn{2}{|c|}{ MTT in FBS } \\
\hline & HepG2 & SH-SY5Y & HepG2 & SH-SY5Y & HepG2 & SH-SY5Y \\
\hline $10 \mathrm{~nm}$ citrate & $0.3 \pm 0.1$ & $0.9 \pm 0.1$ & $0.4 \pm 0.1$ & $0.8 \pm 0.2$ & $05 \pm 0.1$ & $0.9 \pm 0.1$ \\
\hline $20 \mathrm{~nm}$ citrate & $0.5 \pm 0.1$ & $1.0 \pm 0.1$ & $0.6 \pm 0.1$ & $1.2 \pm 0.3$ & $0.8 \pm 0.1$ & $1.0 \pm 0.1$ \\
\hline $40 \mathrm{~nm}$ citrate & $0.8 \pm 0.2$ & $1.2 \pm 0.3$ & $0.8 \pm 0.1$ & $1.6 \pm 0.3$ & $1.8 \pm 0.2$ & $4.2 \pm 0.3$ \\
\hline $60 \mathrm{~nm}$ citrate & $1.0 \pm 0.3$ & $4.5 \pm 0.4$ & $1.1 \pm 0.3$ & $4.1 \pm 0.6$ & $2.3 \pm 0.2$ & $6.3 \pm 0.3$ \\
\hline 10 nm PVP & $0.3 \pm 0.1$ & $0.4 \pm 0.1$ & $04 \pm 0.1$ & $0.6 \pm 0.2$ & $0.5 \pm 0.1$ & $0.8 \pm 0.1$ \\
\hline 20 nm PVP & $0.5 \pm 0.1$ & $1.0 \pm 0.1$ & $0.5 \pm 0.2$ & $1.2 \pm 0.2$ & $0.8 \pm 0.1$ & $0.9 \pm 0.1$ \\
\hline 40 nm PVP & $0.9 \pm 0.2$ & $1.7 \pm 0.2$ & $1.0 \pm 0.3$ & $1.6 \pm 0.3$ & $1.4 \pm 0.2$ & $1.7 \pm 0.2$ \\
\hline 60 nm PVP & $1.0 \pm 0.3$ & $5.0 \pm 0.5$ & $1.3 \pm 0.4$ & $4.2 \pm 0.6$ & $2.2 \pm 0.2$ & $4.0 \pm 0.3$ \\
\hline $\mathrm{AgNO}_{3}$ & $3.5(0.2)$ & $4.8(0.3)$ & - & - & $3.7(0.2)$ & $3.2(0.2)$ \\
\hline
\end{tabular}

For $\mathrm{AgNO}_{3}$ the $\mathrm{IC}_{50}$ value is reported in $\mu \mathrm{mol} / \mathrm{L}$. FBS data (in last two columns) previously reported [29] section, in HS supplemented media, the $10 \mathrm{~nm}$ particles now show the greatest stability over time. Because there is considerable interest in the human health impact of silver nanoparticles used as antimicrobial agents and in the use of silver particles as contrast agents and drug delivery vehicles, we sought to determine how HS might modify the particles in media and the impact it might have on their in vitro cytotoxicity. We have included the data from our previous work in media with FBS in Table 3 to highlight the significant differences in toxicity that were measured in media supplemented with HS using otherwise identical methods. For both the citrate and PVP-stabilized particles, the trend of smaller particles being more toxic was again observed in both HepG2 and $\mathrm{SH}-\mathrm{SY} 5 \mathrm{Y}$ cells despite their improved stability in $\mathrm{HS}$ supplemented media. In HepG2 cells, the absolute $\mathrm{IC}_{50}$ values are approximately half of what was observed in media with FBS, suggesting that in HS the particles are more cytotoxic generally at all sizes. The absolute values for the citrate and PVP stabilized particles at each size in HepG2 cells are the same for each size suggesting that the coating of the particles may not be particularly important for their toxicity in this cell line.

In SH-SY5Y cells, the cytotoxicity of the particles in HS media is more variable when compared with FBS media. For the citrate stabilized particles, there is no difference for the 10 and $20 \mathrm{~nm}$ particles, however, the 40 and $60 \mathrm{~nm}$ particles are more cytotoxic in the HS supplemented media. For the PVP-stabilized particles, there is no measured difference for the 20 and $40 \mathrm{~nm}$ particles, however; the 10 and $60 \mathrm{~nm}$ particles are more cytotoxic in HS supplemented media. These differences in cytotoxicity do not appear to be consistent with differences in the stability of the particles between the two media. It is possible that changing the type of serum is affecting how the particles interact with cells and are metabolized by them. To investigate this we next examined the metal uptake of silver into both cell lines.
We also performed LDH assays for all 8 particles in both HepG2 and SH-SY5Ycells (Table 3). Data for this assay corroborated what was measured using the MTT assay. It is often important to use multiple assays to assess nanotoxicity to confirm that the particles are not interfering with either the dye used to probe the cytotoxicity or the readout itself by scattering light.

\subsection{Uptake of AgNPs by cells}

The total silver uptake of the cells should roughly correlate to the number of particles taken up by the cells. While particles adhered to the outside surface of the cells can lead to artificially high measurements, washing steps are performed to minimize this. We have also attempted to validate the washing procedure by testing for silver in samples without cells. In all cases, silver was not detected after the washing and rinsing procedure in the absence of cells suggesting the procedure is effective at removing unbound particles. This does not exclude the possibility that after some particles may still be adhered to the cell surface rather than the internalized inside the cells.

If the total silver load is key to the mechanism leading to cytotoxicity, then a trend in total silver should correlate with the measured cytotoxicity of the particles in each cell line. In HepG2 cells, there is a direct correlation between metal uptake and toxicity, with the total silver load increasing as the particle size decreases in media supplemented with human serum (Table 4). This trend is observed for both the citrate and PVP stabilized cells. This is very different from what was observed in HepG2 cells with FBS in the media previously where the highest levels of silver were observed for $20 \mathrm{~nm}$ particles and not the $10 \mathrm{~nm}$ ones and no obvious trends are observed. The total amount of silver is also different in media with $\mathrm{HS}$, being twice as great for the $10 \mathrm{~nm}$ particles, but 50-75\% less for larger particles compared to results from FBS supplemented media for citrate stabilized particles. 
Table 4 Metal uptake analysis was performed on cell pellets treated with 10-60 nm silver nanoparticles for $24 \mathrm{~h}$ in media supplemented with human serum compared to media supplemented with fetal bovine serum

\begin{tabular}{llclcc}
\hline Sample & \multicolumn{3}{l}{$\ln \mathrm{HS}$} & & \multicolumn{2}{l}{ In FBS } \\
\cline { 2 - 3 } \cline { 5 - 6 } \cline { 5 - 6 } & HepG2 & SH-SY5Y & & HepG2 & SH-SY5Y \\
\hline $10 \mathrm{~nm}$ citrate & $87 \pm 6$ & $6 \pm 1$ & & $44 \pm 7$ & $37 \pm 5$ \\
$20 \mathrm{~nm}$ citrate & $29 \pm 4$ & $4 \pm 1$ & & $60 \pm 8$ & $58 \pm 8$ \\
$40 \mathrm{~nm}$ citrate & $12 \pm 2$ & $3 \pm 1$ & & $40 \pm 6$ & $63 \pm 8$ \\
$60 \mathrm{~nm}$ citrate & $10 \pm 7$ & $9 \pm 1$ & & $39 \pm 7$ & $100 \pm 10$ \\
$10 \mathrm{~nm}$ PVP & $73 \pm 5$ & $8 \pm 2$ & & $49 \pm 7$ & $21 \pm 5$ \\
$20 \mathrm{~nm}$ PVP & $45 \pm 3$ & $4 \pm 1$ & & $55 \pm 8$ & $25 \pm 6$ \\
$40 \mathrm{~nm}$ PVP & $30 \pm 3$ & $3 \pm 1$ & & $43 \pm 7$ & $28 \pm 6$ \\
$60 \mathrm{~nm}$ PVP & $11 \pm 1$ & $16 \pm 2$ & & $28 \pm 5$ & $67 \pm 8$ \\
\hline
\end{tabular}

Value reported are in ng silver $/ 10^{6}$ cells. FBS data (in last two columns) previously reported [29]

These differences in uptake may arise from the stability of the particles in media over time. Smaller particles being more stable may be bioavailable for a longer period, while for larger particles, a decrease in stability is likely removing them from being bioavailable for uptake. For PVP particles, the $10 \mathrm{~nm}$ value is again double that observed in FBS, with larger particles exhibiting reduced levels. The 20 and $40 \mathrm{~nm}$ particles stabilized with PVP do show considerably greater uptake compared to citrate stabilized particles of the same size. Yet there was no difference in cytotoxicity of the particles suggesting that HepG2 cells can tolerate a higher load of PVP-stabilized particles and that while surface chemistry doesn't appear to affect toxicity, the mechanism of toxicity is not based simply on silver particle load in each cell. It should be noted that the uptake was only measured at one concentration and that the uptake may not be linear across the range of concentrations tested for cytotoxicity. Further experiments could highlight more detail about particle uptake across a wider dynamic range of concentrations.

In SH-SY5Y cells, the uptake of silver did not correlate with toxicity. Here we observed the greatest uptake for $60 \mathrm{~nm}$ particles, the ones that exhibited the lowest cytotoxicity for both citrate and PVP_-stabilized particles. For all particles the measured silver was also significantly lower than what was observed in media with FBS, by factors ranging from 2 to 10 times, yet the measured $I C_{50}$ values were either the same or lower suggesting that in general, the amount of silver uptake in these cells cannot be directly linked to cytotoxicity. This further highlights the importance to select extracellular conditions that best mimic the in vivo environment as the particles are susceptible to changes in the immediate chemical environment.

\section{Conclusions}

Silver nanoparticles are known to rapidly change in aqueous media and in cell culture media, and these changes are dependent on the components of the media. We have previously shown that the presence of antibiotics in the media can influence the measured cytotoxicity of the particles, and here we have demonstrated that the use of human serum also influences the particle stabilities, cytotoxicity and cellular uptake. Following up on our previous work in media supplemented with FBS we have shown that media supplemented with HS has a significantly different impact on the particle life cycles in cell culture media and needs to be considered when developing silver nanoparticles for biomedical applications. Using a system of HepG2 cells in media with HS and antibiotics we observe a very clear relationship between particle cytotoxicity and uptake, with smaller particles accumulating to a greater degree inside the cells and inducing cytotoxicity at lower particle concentrations as measured by mass of silver per volume. If these results can be correlated to actual risk factors for silver particles, then this system may be useful for screening other particles as well with more consistent results. The development of risk assessment for silver nanoparticles, and nanoparticles in general, has been plagued with challenges in reproducing results and developing strong correlations between exposure concentrations and cellular outcomes. In this work, we have highlighted how changing from FBS to $\mathrm{HS}$ results in unexpected changes to silver nanoparticles of different sizes, but that the cytotoxicity of the particles, in at least one cell line, become more predictable and consistent with the accepted paradigm that smaller particles are more cytotoxic due to greater uptake into cells. We also highlight that the use of HS in cell culture media is an important consideration for nanomaterials intended for biomedical purposes as the interactions between the particles and serum alters the stability, toxicity and uptake of the particles.

Acknowledgements We acknowledge the National Research Council of Canada for supporting and funding this research.

\section{Compliance with ethical standards}

Conflict of interest The authors declare that they have no conflict of interest.

\section{References}

1. Baun A, Hartmann NB, Grieger KD, Hansen SF (2009) Setting the limits for engineered nanoparticles in European surface 
waters-are current approaches appropriate? J Environ Monit 11(10):1774-1781. https://doi.org/10.1039/b909730a

2. Calderon-Jimenez $B$, Johnson ME, Montoro Bustos AR, Murphy KE, Winchester MR, Vega Baudrit JR (2017) Silver nanoparticles: technological advances, societal impacts, and metrological challenges. Front Chem 5:6. https://doi.org/10.3389/fchem .2017 .00006

3. El Badawi $L$ (2017) The applications of the nanotechnologies in the agricultural and food domains. J Int Bioethique Ethique Sci 28(2):89-106. https://doi.org/10.3917/jib.282.0089

4. Hofmann-Amtenbrink M, Grainger DW, Hofmann H (2015) Nanoparticles in medicine: current challenges facing inorganic nanoparticle toxicity assessments and standardizations. Nanomedicine 11(7):1689-1694. https://doi.org/10.1016/j. nano.2015.05.005

5. Lai RWS, Yeung KWY, Yung MMN, Djurisic AB, Giesy JP, Leung KMY (2018) Regulation of engineered nanomaterials: current challenges, insights and future directions. Environ Sci Pollut Res Int 25(4):3060-3077. https://doi.org/10.1007/s1135 6-017-9489-0

6. Durán N, Silveira CP, Durán M, Martinez DST (2015) Silver nanoparticle protein corona and toxicity: a mini-review. J Nanobiotechnol 13(1):55. https://doi.org/10.1186/s12951-015-0114-4

7. Pazos-Ortiz E, Roque-Ruiz JH, Hinojos-M Lopez-Esparza J, Donohu-Cornejo A, Cuevas-Gonzalez JC, Espinosa-Cristobal L, Reyes-Lopez SY (2017) Dose-dependent antimicrobial activity of silver nanoparticles on polycaprolactone fibers against grampositive and gram-negative bacteria. J Nanomater 2017:9. https ://doi.org/10.1155/2017/4752314

8. Tang S, Zheng J (2018) Antibacterial activity of silver nanoparticles: structural effects. Adv Healthc Mater 7(13):e1701503. https ://doi.org/10.1002/adhm.201701503

9. Tareq FK, Fayzunnesa M, Kabir MS, Nuzat M (2018) Evaluation of dose dependent antimicrobial activity of self-assembled chitosan, nano silver and chitosan-nano silver composite against several pathogens. Microb Pathog 114:333-339. https://doi. org/10.1016/j.micpath.2017.12.010

10. Das P, Saulnier C, Carlucci C, Allen-Vercoe E, Shah V, Walker VK (2016) Interaction between a broad-spectrum antibiotic and silver nanoparticles in a human gut ecosystem. J Nanomed Nanotechnol 7(5):1000408

11. Salomoni R, Léo $P$, Montemor AF, Rinaldi BG, Rodrigues MFA (2017) Antibacterial effect of silver nanoparticles in Pseudomonas aeruginosa. Nanotechnol Sci Appl 10:115-121. https ://doi.org/10.2147/nsa.s133415

12. AshaRani PV, Low Kah Mun G, Hande MP, Valiyaveettil S (2009) Cytotoxicity and genotoxicity of silver nanoparticles in human cells. ACS Nano 3(2):279-290. https://doi.org/10.1021/nn800 $596 \mathrm{w}$

13. Barbasz A, Ocwieja M, Roman M (2017) Toxicity of silver nanoparticles towards tumoral human cell lines U-937 and HL-60. Colloids Surf B Biointerfaces 156:397-404. https://doi. org/10.1016/j.colsurfb.2017.05.027

14. Kennedy DC, Qian H, Gies V, Yang L (2018) Human serum albumin stabilizes aqueous silver nanoparticle suspensions and inhibits particle uptake by cells. Environ Sci Nano 5(4):863-867. https://doi.org/10.1039/c8en00087e

15. Souza TA, Franchi LP, Rosa LR, da Veiga MA, Takahashi CS (2016) Cytotoxicity and genotoxicity of silver nanoparticles of different sizes in $\mathrm{CHO}-\mathrm{K} 1$ and $\mathrm{CHO}-\mathrm{XRS} 5$ cell lines. Mutat Res Genet Toxicol Environ Mutagen 795:70-83. https://doi.org/10.1016/j. mrgentox.2015.11.002

16. Xue Y, Zhang T, Zhang B, Gong F, Huang Y, Tang M (2016) Cytotoxicity and apoptosis induced by silver nanoparticles in human liver HepG2 cells in different dispersion media. J Appl Toxicol 36(3):352-360. https://doi.org/10.1002/jat.3199
17. Afifi M, Saddick S, Abu Zinada OA (2016) Toxicity of silver nanoparticles on the brain of Oreochromis niloticus and Tilapia zillii. Saudi J Biol Sci 23(6):754-760. https://doi.org/10.1016/j. sjbs.2016.06.008

18. Antsiferova A, Yu B, Demin V, Kashkarov P, Kovalchuk M, Petritskaya E (2015) Extremely low level of Ag nanoparticle excretion from mice brain in in vivo experiments. Crystallogr Rep 61:1020-1026

19. Lacave JM, Fanjul A, Bilbao E, Gutierrez N, Barrio I, Arostegui I, Cajaraville MP, Orbea A (2017) Acute toxicity, bioaccumulation and effects of dietary transfer of silver from brine shrimp exposed to PVP/PEI-coated silver nanoparticles to zebrafish. Comp Biochem Physiol C Toxicol Pharmacol. https://doi. org/10.1016/j.cbpc.2017.03.008

20. Lee JH, Kim YS, Song KS, Ryu HR, Sung JH, Park JD, Park HM, Song NW, Shin BS, Marshak D, Ahn K, Lee JE, Yu IJ (2013) Biopersistence of silver nanoparticles in tissues from Sprague-Dawley rats. Part Fibre Toxicol 10:36. https://doi.org/10.1186/1743-8977-10-36

21. Yang L, Kuang H, Zhang W, Aguilar ZP, Wei H, Xu H (2017) Comparisons of the biodistribution and toxicological examinations after repeated intravenous administration of silver and gold nanoparticles in mice. Sci Rep 7(1):3303. https://doi. org/10.1038/s41598-017-03015-1

22. Azimzada A, Tufenkji N, Wilkinson KJ (2017) Transformations of silver nanoparticles in wastewater effluents: links to $\mathrm{Ag}$ bioavailability. Environ Sci Nano 4(6):1339-1349. https://doi. org/10.1039/c7en00093f

23. Beer C, Foldbjerg R, Hayashi Y, Sutherland DS, Autrup H (2012) Toxicity of silver nanoparticles-nanoparticle or silver ion? Toxicol Lett 208(3):286-292. https://doi.org/10.1016/j.toxle t.2011.11.002

24. Behra R, Sigg L, Clift MJD, Herzog F, Minghetti M, Johnston B, Petri-Fink A, Rothen-Rutishauser B (2013) Bioavailability of silver nanoparticles and ions: from a chemical and biochemical perspective. J R Soc Interface 10(87):20130396. https://doi. org/10.1098/rsif.2013.0396

25. Doolette CL, McLaughlin MJ, Kirby JK, Batstone DJ, Harris $\mathrm{HH}, \mathrm{Ge}$ H, Cornelis G (2013) Transformation of PVP coated silver nanoparticles in a simulated wastewater treatment process and the effect on microbial communities. Chem Cent J 7:46. https://doi. org/10.1186/1752-153X-7-46

26. Lubick N (2008) Nanosilver toxicity: ions, nanoparticles-or both? Environ Sci Technol 42(23):8617

27. Molleman B, Hiemstra T (2017) Time, pH, and size dependency of silver nanoparticle dissolution: the road to equilibrium. Environ Sci Nano 4(6):1314-1327. https://doi.org/10.1039/c6en00564k

28. Tejamaya M, Romer I, Merrifield RC, Lead JR (2012) Stability of citrate, PVP, and PEG coated silver nanoparticles in ecotoxicology media. Environ Sci Technol 46(13):7011-7017. https://doi. org/10.1021/es2038596

29. Kennedy DC, Gies V, Jezierski A, Yang L (2019) Changes in the physical properties of silver nanoparticles in cell culture media mediate cellular toxicity and uptake. J Nanopartilce Res. https ://doi.org/10.1007/s11051-019-4535-0

30. Peng H, Zhang X, Wei Y, Liu W, Li S, Yu G, Fu X, Cao T, Deng X (2012) Cytotoxicity of silver nanoparticles in human embryonic stem cell-derived fibroblasts and an L-929 cell line. J Nanomater 2012:9. https://doi.org/10.1155/2012/160145

Publisher's Note Springer Nature remains neutral with regard to jurisdictional claims in published maps and institutional affiliations. 